\title{
Analisis Pengaruh Penambahan Fan pada Instalasi Air Conditioner dan Putaran Engine terhadap Temperatur Cabin dan Coeffisient of Performance
}

\author{
Ahmad Yani ${ }^{1}$, Yano Hurung Anoi ${ }^{2}$, Miswan Prastiawan ${ }^{3}$ \\ Jurusan Teknik Mesin Sekolah Tinggi Teknologi Industri Bontang ${ }^{1,2}$ \\ Jl. Brigjen Katamso No.40 Bontang, Kalimantan Timur, Indonesia ${ }^{1,2}$ \\ Karyawan Dewo AC Bontang ${ }^{3}$ \\ Jl. Ciptomangunkusumo No.28 Bontang, Kalimantan Timur, Indonesia ${ }^{3}$ \\ Email: yanibima@gmail.com ${ }^{1}$, yanodayak@gmail.com², prasetya_mp@yahoo.com³
}

\begin{abstract}
Abstrak
Pendingin adalah suatu proses yang dilakukan untuk menurunkan temperatur suhu. Pendingin dilakukan dengan cara memindahkan kalor dari objek yang akan didinginkan ke lingkungan. Maka dari itu dalam proses pendinginan pada sistem AC (air conditioner) mobil diperlukan media yang digunakan sebagai pendingin yaitu menggunakan refrigeran. Penelitian ini dilakukan dengan cara memodifikasi instalasi AC mobil dengan melakukan penembahan fan, ini bertujuan untuk memaksimalkan kinerja semua komponen AC yang terdapat pada mobil Mitsubishi Triton double cabin. Fan yang digunakan mempunyai daya sebesar 12 Volt dan hanya beroperasi ketika AC dinyalakan dan AC hanya bisa digunakan ketika mesin menyala. Oleh sebab itu baterai mobil pun tetap awet setelah penambahan fan ini karena saat fan berputar baterai akan tetap terisi oleh alternator pengisian yang bergerak mengikuti putaran mesin, sehingga tidak begitu membebani daya mobil yang berkapasitas $2500 \mathrm{cc}$. Berdarakan hasil penelitian, temperatur terendah terjadi setelah penambahan fan dengan nilai temperatur sebesar $14,4^{\circ} \mathrm{C}$ pada putaran mesin 3000 dan temperatur tertinggi sebesar $21,3{ }^{\circ} \mathrm{C}$ pada putaran mesin $1000 \mathrm{rpm}$. Sedangkan sebelum penambahan fan temperatur terendah sebesar $20^{\circ} \mathrm{C}$ pada putaran mesin 3000 dan temperatur tertinggi sebesar $24,3{ }^{\circ} \mathrm{C}$ pada putaran mesin $1000 \mathrm{rpm}$. Sedangkan nilai COP (Coeffisient Of Performance) Carnot tertinggi terjadi setelah penambahan fan dengan nilai nilai COP Carnot 10,730 pada putaran mesin $1000 \mathrm{rpm}$ dan nilai COP Carnot terendah 9,729 pada putaran mesin $3000 \mathrm{rpm}$. Sedangkan sebelum penambahan fan nilai COP Carnot tertinggi sebesar 10,299 pada putaran mesin 1000 dan nilai COP Carnot terendah sebesar 8,613 pada putaran mesin $3000 \mathrm{rpm}$.
\end{abstract}

Kata kunci: Fan, putaran engine, temperatur, dan COP.

\section{Pendahuluan}

Pengkondisian udara adalah suatu proses mendinginkan udara sehingga dapat mencapai temperatur dan kelembaban sesuai dengan yang dipersyaratkan terhadap kondisi udara dari suatu ruangan tertentu. Sistem penyegaran udara untuk industri dirancang untuk memperoleh temperatur, kelembaban, serta distribusi udara yang sesuai dengan yang dipersyaratkan oleh proses dan peralatan yang ada pada industri tersebut. Sistem refrigerasi mempunyai komponen utama kompresor, kondensor, katup ekspansi, dan evaporator [1].
Ketika berkendara di dalam mobil, kondisi lingkungan di dalamnya sangat mempengaruhi kenyamanan kerja pengemudi dan penumpang. Salah satunya adalah panas, sehingga diperlukan fasilitas pengaturan udara yaitu air conditioner (AC). Kondisi tropis seperti di Indonesia memungkinkan AC lebih bertujuan untuk mendinginkan ruangan daripada memanaskan ruangan (di daerah Eropa biasanya AC untuk pemanas). Permasalahan panas ini jika tidak diatasi, maka akan mengganggu kosentrasi berkendara yang bisa menimbulkan bahaya yang mengancam keselamatan jiwa. Secara 
garis besar AC berfungsi untuk mengatur suhu udara, mengatur sirkulasi udara, mengatur kelembaban udara dan mengatur kebersihan udara [2].

Fitur penyejuk udara atau $\mathrm{AC}$ telah menjadi bagian penting dalam sebuah kendaraan. Tidak hanya di daerah tropis, di daerah sub tropis pun perangkat ini sangat diperlukan. Khusus di daerah tropis yang panas, perangkat AC lebih berfungsi sebagai pendingin. Apalagi di daerah tambang, dengan kondisi jalanan yang tidak aspal, suhu udara yang sangat panas, dan terdapat banyak debu yang berterbangan, AC diperlukan untuk mendapatkan kenyamanan saat berkendara (berada dalam cabin). Ini penting, sebab kenyamanan berkendara akan mempengaruhi perilaku di jalan, sehingga pengendara menjadi tenang dan tidak emosional, selain itu dari sisi keamanan pengendara dan penumpang lebih terjamin keamanannya karena pintu dan jendela mobil harus ditutup waktu AC dihidupkan, hal tersebut menyebabkan penggunaan $\mathrm{AC}$ pada mobil semakin banyak [4].

Memodifikasi AC ini bertujuan untuk memaksimalkan kinerja semua komponen AC yang terdapat pada mobil Mitsubishi Triton double cabin yang mengalami penurunan fungsi setelah beroperasi beberapa tahun, terutama unit yang berada pada lingkungan kerja tambang maupun kondisi sekitar yang kurang bersahabat dan juga untuk meminimalisir kerusakan komponen AC akibat kelalaian operator. Langkah ini diaplikasikan pada mobil Mitsubishi Triton double cabin keluaran tahun 2013 dan sebelumnnya yang telah melakukan servis berat biasanya saat part mengalami kebocoran, masalah kompresor, maupun kurangnya daya pelepasan kalor oleh fan bawaan mobil triton itu sendiri. Agar tercapai efisiensi yang diinginkan dan semua komponen berfungsi dengan normal kembali. Energi yang dibutuhkan untuk menggerakkan extra fan ini tidak terlalu besar, fan ini mempunyai daya sebesar 12 Volt dan hanya beroperasi ketika AC dinyalakan dan AC hanya bisa digunakan ketika mesin menyala oleh sebab itu baterai pun tetap awet setelah penambahan fan ini karena saat fan berputar baterai akan tetap terisi oleh alternator pengisian yang bergerak mengikuti putaran mesin, sehingga tidak begitu membebani daya mobil yang berkapasitas $2500 \mathrm{cc}$.

\section{Tinjauan Pustaka}

\section{Pengertian sistem pendingin}

Pendingin adalah suatu proses yang dilakukan untuk menurunkan temperatur suhu. Pendingin dilakukan dengan cara memindahkan kalor dari objek yang akan didinginkan ke lingkungan. Maka dari itu dalam proses pendinginan pada system AC mobil diperlukan media yang digunakan pendingin yaitu menggunakan refrigeran.

Pendinginan dapat terjadi secara alami maupun secara paksa. Pendinginan secara alami yaitu dimana proses pendingin berlangsung dengan sendirinya, sedangkan pendingin secara paksa yaitu proses pendingin yang berlangsung akibat campur tangan manusia. Pendinginan menurut siklusnya terbagi atas dua bagian, yaitu pendinginan terbuka dan pendinginan tertutup yang memiliki penjelasan secara singkat sebagai berikut [4]:

1. Pendinginan Terbuka

Pendinginan terbuka yaitu proses dimana fluida bekerja secara irreversible (tidak berulang/kembali), dengan melakukan pendinginan hanya sekali saja. Setelah fluida melakukan pendinginan maka fluida kerja dikembalikan atau dibuang.

2. Pendinginan Tertutup

Pendinginan tertutup yaitu proses pendinginan yang fluidanya bekerja secara reversible (berulang-ulang). Dimana pada saat fluida selesai melakukan pendinginan, fluida akan kembali didinginkan sehingga bisa digunakan kembali untuk proses pendinginan. Untuk membuat fluida tersebut dapat mendinginkan lagi, diperlukan beberapa peralatan tambahan.

Proses pendinginan pada sistem AC kendaraan dilakukan dengan cara memanfaatkan refrigeran untuk mengambil 
panas, dengan aliran refrigeran sebagai berikut [2]:

1. Kompresor melepaskan refrigeran yang bertemperatur dan bertekanan tinggi.

2. Refrigeran di condenser dicairkan kembali.

3. Setelah itu refrigeran masuk di receiver/dryer untuk disaring dan dialirkan ke evaporator melalui expansion valve.

4. Expansion valve merubah cairan refrigeran menjadi campuran dan cairan yang bertemperatur dan bertekanan rendah.

5. Refrigeran bersuhu rendah dan berbentuk kabut tersebut mengalir ke dalam evaporator dan menguap, mengambil panas dari hangat yang dilewatkan di evaporator. Seluruh cairan berubah menjadi gas yang mempunyai panas laten tersebut mengalir ke dalam kompresor untuk diproses kembali.

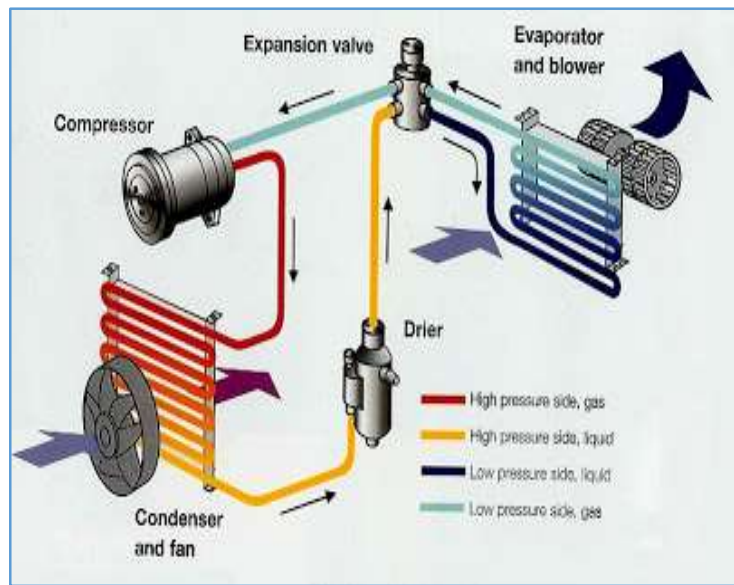

Gambar 1. Diagram alir refrigeran [2].

\section{Siklus pendinginan Air Conditioner System}

Ada empat siklus pendinginan, dan refrigeran disirkulasikan berulang kali dengan perubahan-perubahan sebagai berikut (Cair-Uap-Cair) [3]. Skema proses pendinginan dapat dilihat pada gambar 2 .



Gambar 2. Diagram aliran [3].

1. Evaporasi

Refrigeran dirubah dari cairan ke gas dalam evaporator. Cairan refrigeran dikabutkan oleh hisapannya sendiri dimana saat proses evaporasi panas latent dibutuhkan dari udara disekitar evaporator.

Udara melepaskan panas untuk didinginkan, dan dialirkan ke dalam ruang dalam operator cabin oleh cooling fan; sambil menurunkan temperatur ruangan itu. Cairan refrigeran itu disalurkan dari expansion valve di dalam evaporator kemudian sekaligus menjadi uap refrigeran, dan perubahan itu terjadi berulang kali dari kondisi cair ke gas.

Tekanan dan temperatur dalam perubahan itu selalu berkaitan, jika tekanan di-set maka temperatur juga akan di-set. Untuk pengabutan yang dilakukan saat temperatur lebih rendah dari perubahan itu (Cair - Gas) dalam kondisi seperti di atas, tekanan dalam evaporator juga harus dibuat tetap rendah. Karena itu, gas dari refrigeran yang dikabutkan haruslah dikurangi secara kontinyu keluar evaporator oleh hisapan kompresor.

\section{Kompresi}

Refrigeran ditekan dalam kompresor sampai kondisinya menjadi cair dengan temperatur yang tinggi. Gas refrigeran dalam evaporator dihisap oleh kompresor akan membuat tekanannya tetap rendah di dalam evaporator, dan untuk membuat cairan refrigeran menjadi gas secara dinamis pada temperatur yang rendah $\left(0^{\circ} \mathrm{C}\right)$. Maka tekanan gas refrigeran ditekan dalam silinder, dan berubah menjadi tinggi, sehingga temperatur dan tekanan 
refrigeran akan mudah menjadi cair walaupun proses pendinginan dalam temperatur yang lebih tinggi. Kerja kompresi (Btu/lb) merupakan perubahan entalpy pada proses dibawah ini:

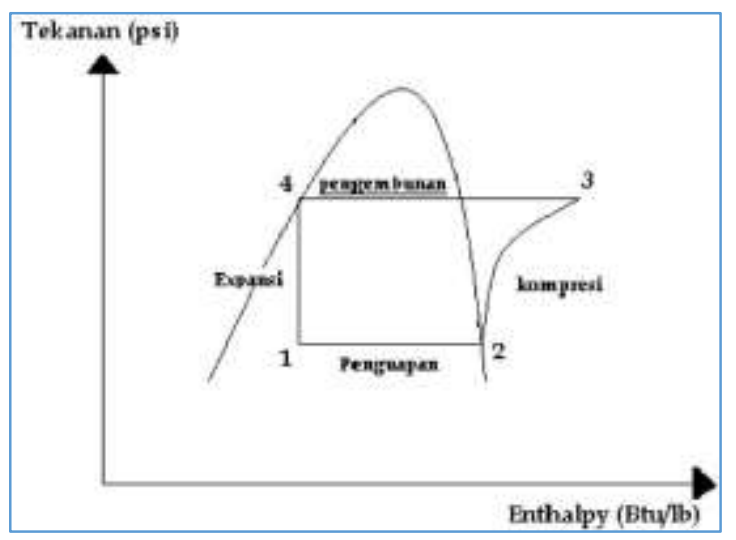

Gambar 3. Daur kompresi uap ideal dalam diagram tekanan-enthalpy [3].

\section{Kondensasi}

Refrigeran dirubah dari gas menjadi cair dan didinginkan dari temperatur yang tinggi didalam condenser. Refrigeran yang bertemperatur dan bertekanan tinggi itu dipancarkan dalam condensor menjadi cairan dan disalurkan ke receiver drier. Hal itu juga dinamakan proses kondensasi panas. Panas yang tinggi dari refrigeran itu dapat dikeluarkan oleh condensor sehingga refrigeran menjadi dingin dan dapat melakukan proses penyerapan panas di ruang kabin operator.

\section{Ekspansi}

Tekanan cairan refrigeran diturunkan oleh expansion valve. Hal itu disebut proses ekspansi, dimana gas bertekanan itu dikabutkan dengan mudah dalam evaporator sehingga refrigeran menjadi gas, dan expansion valve ini mengatur aliran cairan refrigeran sambil menurunkan tekanannya.

Cairan refrigeran yang dikabutkan ini dalam evaporator di-set oleh tingkat pendinginan yang harus dilakukan dibawah temperatur pengabutan. Untuk itu, penting untuk mengontrol jumlah refrigeran yang dibutuhkan dengan melakukan pengecekan yang benar.

\section{Coeffisient of Performance (COP Carnot) \\ Coeffisient of Performance (COP)} adalah efisiensi siklus yang dinyatakan sebagai rasio penyerapan panas pada ruang pendingin yang setara dengan energi panas masuk ke kompresor. Untuk mengitung COP Carnot menggunakan persamaan berikut.

$$
\mathrm{COP}_{\text {Carnot }}=\frac{T_{L}}{T_{H^{-}} T_{L}}
$$

Keterangan:

$$
\begin{aligned}
\mathrm{COP} & =\text { Coeffisient of Performance } \\
\mathrm{TL} & =\text { Temperatur refrigeran saat } \\
& \text { menyerap kalor (temperatur } \\
& \text { evaporator) } \\
\mathrm{TH} & =\text { Temperatur refrigeran saat } \\
& \text { melepas kalor (temperatur } \\
& \text { kondensor) }
\end{aligned}
$$

\section{Metode Penelitian}

Penelitian dilakukan pada Bulan April 2018 di Workshop Dewo AC Bontang.

Bahan dan alat penelitian yang digunakan pada penelitian ini antara lain :

1. Mobil Mitsubishi Triton double cabin

2. Pressure gauge

3. Thermometer

4. Tachometer

5. Fan

6. Refrigeran R-134

7. Alat tulis

Prosedur pengambilan data penelitian sebagai berikut:

a) Tahap Persiapan

1. Persiapan dan pemasangan seluruh alat ukur yang digunakan dalam pengujian,

2. Kalibrasi seluruh alat ukur yang dipakai untuk penelitian.

b) Tahap Pengujian

1. Nyalakan engine dan atur putaran engine sesuai yang ditentukan,

2. Memasang alat ukur penelitian,

3. Pengambilan data temperatur evaporator sebelum penambahan fan,

4. Pengambilan data temperatur kondensor sebelum penambahan fan,

5. Pengambilan data temperatur sebelum penambahan fan, 
6. Melakukan perhitungan nilai COP pada tiap variasi putaran engine yang ditentukan,

7. Memodifikasi AC dengan menambah fan pada sistem AC,

8. Pengambilan data temperatur evaporator setelah penambahan fan,

9. Pengambilan data temperatur kondensor setelah penambahan fan,

10. Pengambilan data temperatur setelah penambahan fan,

11. Melakukan perhitungan nilai COP pada tiap variasi putaran engine yang ditentukan,

12. Menganalisa dan mengolah data penelitian yang didapatkan,

13. Menyimpulkan hasil penelitian.

Berikut ini merupakan gambar instalasi AC sebelum modifikasi dan gambar instalasi AC setelah modifikasi.

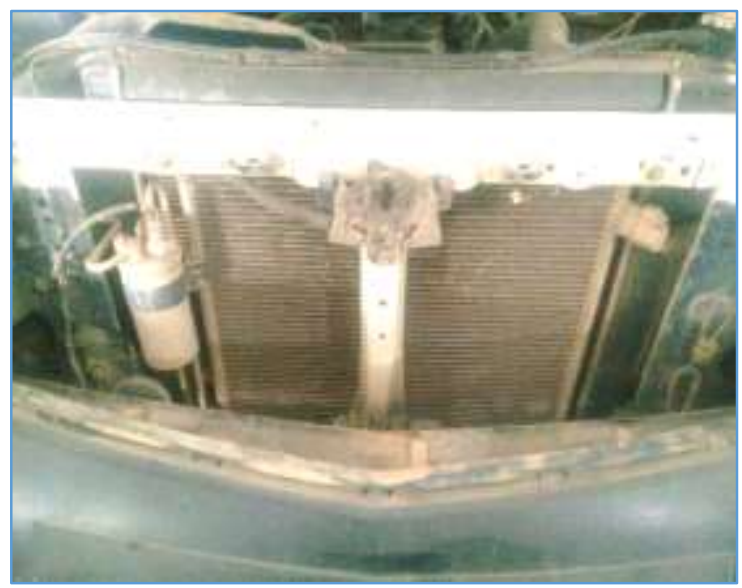

Gambar 4. Instalasi AC sebelum penambahan fan



Gambar 5. Instalasi AC setelah penambahan fan

\section{Hasil dan Pembahasan}

\section{Hasil Penelitian}

Tabel 1. Data rata-rata penelitian sebelum penambahan fan

\begin{tabular}{cccc}
\hline $\begin{array}{l}\text { Putaran } \\
\text { engine } \\
(\mathrm{rpm})\end{array}$ & $\begin{array}{c}\text { Temp. } \\
\text { Evaporator } \\
\left({ }^{\circ} \mathrm{C}\right)\end{array}$ & $\begin{array}{c}\text { Temp. } \\
\text { Kondensor } \\
\left({ }^{\circ} \mathrm{C}\right)\end{array}$ & $\begin{array}{c}\text { Temp. } \\
\text { Cabin } \\
\left({ }^{\circ} \mathrm{C}\right)\end{array}$ \\
\hline 1000 & 9,2 & 36,6 & 24,3 \\
\hline 1500 & 8,8 & 37,2 & 23,9 \\
\hline 2000 & 8,6 & 38,1 & 22,3 \\
\hline 2500 & 8,5 & 39,6 & 21,9 \\
\hline 3000 & 7,8 & 40,4 & 20,0 \\
\hline
\end{tabular}

Tabel 2. Data rata-rata penelitian setelah penambahan fan

\begin{tabular}{cccc}
\hline $\begin{array}{l}\text { Putaran } \\
\text { engine } \\
(\mathrm{rpm})\end{array}$ & $\begin{array}{c}\text { Temp. } \\
\text { Evaporator } \\
\left({ }^{\circ} \mathrm{C}\right)\end{array}$ & $\begin{array}{c}\text { Temp. } \\
\text { Kondensor } \\
\left({ }^{\circ} \mathrm{C}\right)\end{array}$ & $\begin{array}{c}\text { Temp. } \\
\text { Cabin } \\
\left({ }^{\circ} \mathrm{C}\right)\end{array}$ \\
\hline 1000 & 8,3 & 34,5 & 21,3 \\
\hline 1500 & 7,7 & 34,7 & 20,1 \\
\hline 2000 & 7,6 & 35,5 & 17,5 \\
\hline 2500 & 7,4 & 35,6 & 15,5 \\
\hline 3000 & 7,2 & 36,0 & 14,4 \\
\hline
\end{tabular}

\section{Penambahan fan terhadap temperatur kabin}

Dari hasil pengujian temperatur pada cabin dengan variasi putaran mesin didapat data penelitian seperti pada tabel 3 .

Tabel 3. Data hasil pengujian temperatur cabin

\begin{tabular}{ccc}
\hline $\begin{array}{c}\text { Putaran } \\
\text { engine } \\
(\mathrm{rpm})\end{array}$ & $\begin{array}{c}\text { Temp. cabin } \\
\text { sebelum } \\
\text { penambahan } \\
\text { fan }\left({ }^{\circ} \mathrm{C}\right)\end{array}$ & $\begin{array}{c}\text { Temp. cabin } \\
\text { setelah } \\
\text { penambahan } \\
\text { fan }\left({ }^{\circ} \mathrm{C}\right)\end{array}$ \\
\hline 1000 & 24.300 & 21.300 \\
\hline 1500 & 23.900 & 20.100 \\
\hline 2000 & 22.300 & 17.500 \\
\hline 2500 & 21.900 & 15.500 \\
\hline 3000 & 20.000 & 14.400 \\
\hline
\end{tabular}

Dari tabel 3 di atas selanjutnya data temperatur cabin sebelum dan sesudah penambahan fan didapat kemudian ditampilkan dalam bentuk grafik untuk memudahkan dalam membandingkan hasil penelitian yang sudah dilakukan. Gambar/grafik putaran mesin vs temperatur cabin sebelum dan setelah penambahan fan seperti pada gambar 6 . 


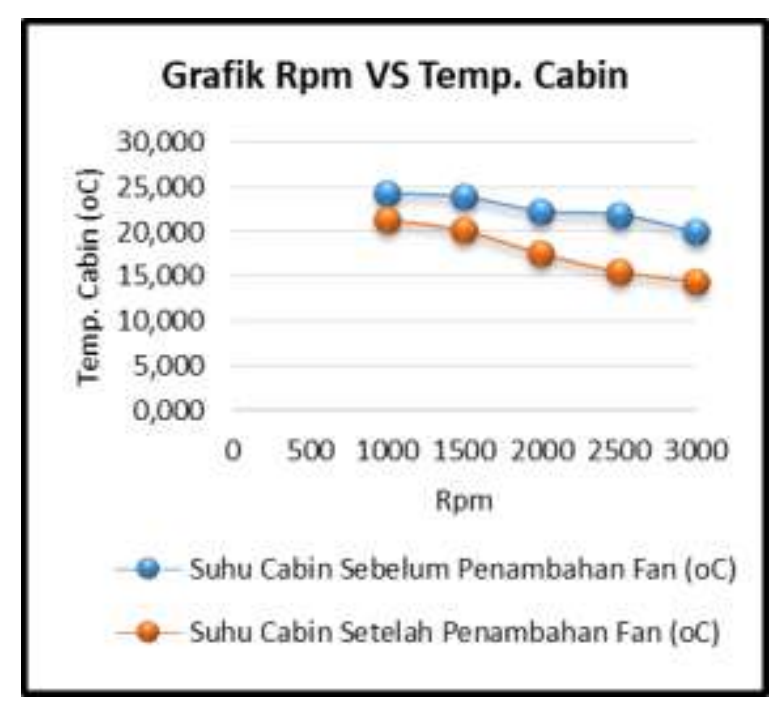

Gambar 6. Grafik putaran engine vs temperatur cabin sebelum dan setalah penambahan fan.

Pada grafik putaran engine vs temperatur cabin sebelum dan setelah penambahan fan bisa dibedakan dengan jelas perbandingan suhu cabin, jadi kesimpulan yang dapat kita ambil yaitu terdapat pengaruh dengan adanya penambahan fan yang mengakibatkan temperatur cabin pada mobil menjadi lebih rendah dibandingkan temperatur sebelum penambahan fan, sehingga kondisi dalam cabib lebih dingin. Kalau dilihat secara detail dari gambar 6 baik grafik sebelum dan setelah penambahan fan memperlihatkan dengan bertambahnya putaran engine maka temperatur dalam cabin semakin menurun. Misalnya dimulai dari sebelum penambahan fan putaran terendah yaitu $1000 \mathrm{rpm}$ diperoleh data temperatur $24,3{ }^{\circ} \mathrm{C}$, pada $1500 \mathrm{rpm}$ diperoleh temperatur $23,9{ }^{\circ} \mathrm{C}$, pada 2000 rpm diperoleh temperatur $22,3{ }^{\circ} \mathrm{C}$, pada $2500 \mathrm{rpm}$ diperoleh temperatur $21,9{ }^{\circ} \mathrm{C}$, pada $3000 \mathrm{rpm}$ diperoleh temperatur $20^{\circ} \mathrm{C}$. Sedangkan pada variabel penambahan fan putaran terendah yaitu $1000 \mathrm{rpm}$ diperoleh data temperatur $21,3{ }^{\circ} \mathrm{C}$, pada $1500 \mathrm{rpm}$ diperoleh temperatur $20,1{ }^{\circ} \mathrm{C}$, pada 2000 rpm diperoleh temperatur $17,5{ }^{\circ} \mathrm{C}$, pada $2500 \mathrm{rpm}$ diperoleh temperatur $15,5{ }^{\circ} \mathrm{C}$, pada $3000 \mathrm{rpm}$ diperoleh temperatur 14,4 ${ }^{\circ} \mathrm{C}$. Dari gambar 6 di atas dapat kita simpulkan temperatur terendah terjadi setelah penambahan fan dengan nilai temperatur sebesar $14,4{ }^{\circ} \mathrm{C}$ pada putaran mesin $3000 \mathrm{rpm}$ dan temperatur tertinggi sebesar $21,3{ }^{\circ} \mathrm{C}$ pada putaran mesin 1000 rpm. Sedangkan sebelum penambahan fan temperatur terendah sebesar $20{ }^{\circ} \mathrm{C}$ pada putaran mesin 3000 dan temperatur tertinggi sebesar $24,3{ }^{\circ} \mathrm{C}$ pada putaran mesin $1000 \mathrm{rpm}$.

\section{Penambahan fan terhadap COP Carnot}

Dari data hasil pengujian temperatur evaporator dan kondensor yang terdapat pada tabel 1 dan tabel 2 dikonversi terlebih dahulu dalam satuan derajat Kelvin sehingga dapat dianalisa dengan menggunakan rumus COP Carnot seperti berikut ini.

$$
\begin{aligned}
\operatorname{COP}_{\text {Carnot }}= & \frac{T_{L}}{T_{H}-T_{L}} \\
\operatorname{COP}_{\text {Carnot }}= & \frac{282,200}{309,600-282,200} \\
& =10,299
\end{aligned}
$$

Analisa data COP Carnot fan di atas merupakan contoh perhitungan yang mewakili data yang lain. Contoh perhitungan di atas diambil pada tabel 1 baris pertama.

Untuk hasil analisa data keselurusan COP Carnot sebelum penambahan fan dan COP Carnot sesudah penambahan fan dapat dilihat pada tabel 4 .

Tabel 4. Data hasil analisa COP Carnot

\begin{tabular}{ccc}
$\begin{array}{c}\text { Putaran } \\
(\mathrm{rpm})\end{array}$ & $\begin{array}{c}\text { COP Carnot } \\
\text { sebelum } \\
\text { penambahan } \\
\text { fan }\left({ }^{\circ} \mathrm{C}\right)\end{array}$ & $\begin{array}{c}\text { COP Carnot } \\
\text { setelah } \\
\text { penambahan } \\
\text { fan }\left({ }^{\circ} \mathrm{C}\right)\end{array}$ \\
\hline 1000 & 10.299 & 10.737 \\
\hline 1500 & 9.923 & 10.396 \\
\hline 2000 & 9.546 & 10.057 \\
\hline 2500 & 9.051 & 9.943 \\
\hline 3000 & 8.613 & 9.729 \\
\hline
\end{tabular}

Dari tabel 4 selanjutnya hasil perhitungan COP Carnot sebelum penambahan fan dan COP Carnot setelah penambahn fan didapat kemudian ditampilkan dalam bentuk grafik untuk memudahkan dalam membandingkan hasil analisa data penelitian yang sudah 
dilakukan. Grafik putaran engine vs COP Carnot seperti pada gambar 7 .

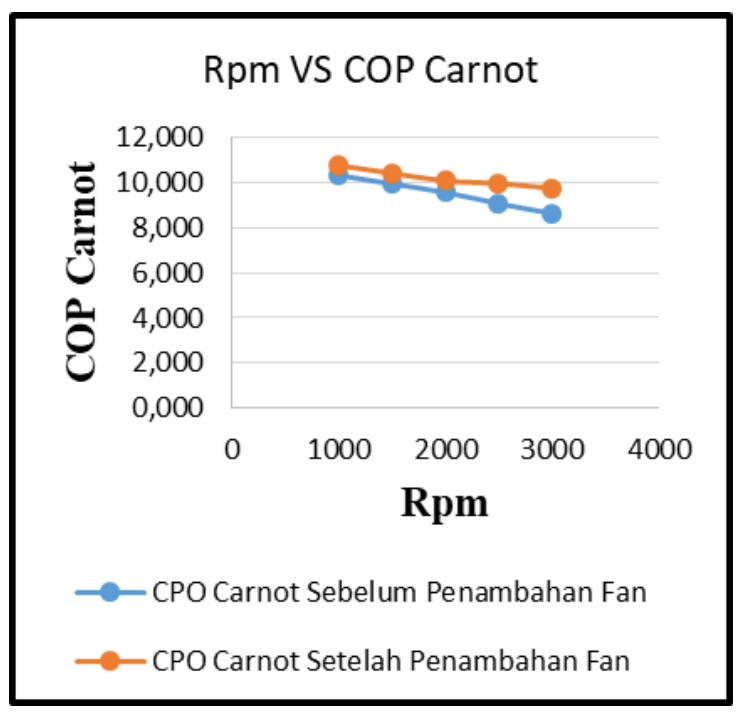

Gambar 7. Grafik rpm vs COP Carnot sebelum dan setalah penambahan fan

Pada grafik rpm vs nilai COP Carnot sebelum dan setelah penambahan fan bisa dibedakan dengan jelas perbandingan nilai COP Carnot, jadi kesimpulan yang dapat kita ambil yaitu terdapat pengaruh dengan adanya penambahan fan yang mengakibatkan nilai COP Carnot pada mobil menjadi lebih tinggi dibandingkan nilai COP Carnot sebelum penambahan fan. Kalau dilihat secara detail dari gambar 7 baik grafik COP Carnot sebelum penambahan fan dan grafik COP sesudah penambahan fan memperlihatkan dengan bertambahnya putaran engine maka nilai COP Carnot semakin menurun, misalnya dimulai dari sebelum penambahan fan COP Carnot terendah pada putaran $1000 \mathrm{rpm}$ diperoleh data 10, 299, pada $1500 \mathrm{rpm}$ diperoleh temperatur 9,923, pada $2000 \mathrm{rpm}$ diperoleh 9,546, pada $2500 \mathrm{rpm}$ diperoleh temperatur 9,051, dan pada $3000 \mathrm{rpm}$ diperoleh 8,613. Sedangkan pada penambahan fan putaran terendah yaitu $1000 \mathrm{rpm}$ diperoleh data COP Carnot sebesar 10,730, pada $1500 \mathrm{rpm}$ diperoleh 10,390, pada $2000 \mathrm{rpm}$ diperoleh 10,050, pada $2500 \mathrm{rpm}$ diperoleh 9,943 , dan pada $3000 \mathrm{rpm}$ diperoleh nilai COP Carnot sebesar 9,729. Dari gambar 7 dapat kita simpulkan nilai COP Carnot tertinggi terjadi pada penambahan fan dengan nilai
COP Carnot 10,730 pada putaran mesin 1000 rpm. dan nilai COP Carnot terendah 9,729 pada putaran mesin $3000 \mathrm{rpm}$. Sedangkan sebelum penambahan fan nilai COP Carnot tertinggi sebesar 10,299 pada putaran mesin 1000 dan nilai COP Carnot terendah sebesar 8,613 pada putaran mesin $3000 \mathrm{rpm}$.

\section{Kesimpulan}

Berdarakan tujuan penelitian ini dapat disimpulkan hasil penelitian dari pengaruh penambahan fan terhadap kualitas pendinginan air conditioner pada mobil Mitsubishi Triton double cabin adalah temperatur terendah terjadi pada penambahan fan dengan nilai temperatur sebesar $14,4{ }^{\circ} \mathrm{C}$ pada putaran mesin 3000 dan temperatur tertinggi sebesar $21,3{ }^{\circ} \mathrm{C}$ pada putaran mesin $1000 \mathrm{rpm}$. Sedangkan sebelum penambahan extra fan temperatur terendah sebesar $20{ }^{\circ} \mathrm{C}$ pada putaran mesin 3000 dan temperatur tertinggi sebesar 24,3 ${ }^{\circ} \mathrm{C}$ pada putaran mesin $1000 \mathrm{rpm}$. Nilai COP Carnot tertinggi terjadi pada penambahan fan dengan nilai nilai COP Carnot 10,730 pada putaran mesin 1000 rpm dan nilai COP Carnot terendah 9,729 pada putaran mesin $3000 \mathrm{rpm}$. Sedangkan sebelum penambahan fan nilai COP Carnot tertinggi sebesar 10,299 pada putaran mesin 1000 dan nilai COP Carnot terendah sebesar 8,613 pada putaran mesin 3000 rpm.

\section{Referensi}

[1]. Tjahjono \& Desi Arna (2014). Optimasi Kecepatan Udara Pada Kondensor Terhadap Prestasi Kinerja AC mobil Dengan Fluida Kerja Freon, jurnal media Mesin Vol. 15 No. 2 ISSN. 1411-4348. Jurusan Teknik Mesin Universitas Muhammadiyah Surakarta.

[2]. Gunadi (2011). Sistem kelistrikan bodi. Penerbit Mentari Pustaka. Yogyakarta 
[3]. Kurnia, R. Irawan (2016). Analisa pengaruh tekanan kompresor air conditioner terhadap temperatur ruang kabin operator pada hydraulic excavator komatsu PC2000-8. Skripsi Teknik Mesin Universitas Trunajaya Bontang.

[4]. Sudarman, (2004). Siklus Daya Thermal. Universitas Muhammadiyah Malang.

[5]. Saputra, A.R;

Widiyatmoko\&Azharudin (2015). Coefisien of performance (COP) mini frizzer daging ayam kapasitas $4 \mathrm{~kg}$. Jurnal teknik pendingin dan tata udara politeknik negeri sekayu (PETRA). Volume 1, No. 1 November 2015. 